\title{
Broilerinlihan elinkaariarviointi
}

Juha Grönroos $^{1)}$, Juha-Matti Katajajuuri ${ }^{2)}$, Kirsi Usva ${ }^{2)}$, Yrjö Virtanen ${ }^{2)}$, Ilkka Sipilä²), Eija Venäläinen $^{2)}$, Sirpa Kurppa ${ }^{2)}$, Riikka Tanskanen ${ }^{2)}$, Tuomas Mattila ${ }^{1)}$ ja Hanna Virtanen ${ }^{2)}$

${ }^{1)}$ Suomen ympäristökeskus, PL 140, 00251 Helsinki, etunimi.sukunimi@ymparisto.fi

${ }^{2)}$ Maa- ja elintarviketalouden tutkimuskeskus,31600 Jokioinen, etunimi.sukunimi@mtt.fi

\section{Tiivistelmä}

Hankkeen tavoitteena oli elinkaariarvioinnin menetelmin arvioida hunajamarinoitujen broilerin fileesuikaleiden tuotannon aiheuttama ympäristökuormitus todelliseen toimintoverkkoon ja prosesseihin perustuen, sekä arvioida niiden pohjalta tuotannosta aiheutuvat ympäristövaikutukset. Tavoitteena oli selvittää, mitkä tuotantovaiheet vaikuttavat ympäristövaikutuksiin eniten, sekä etsiä ja tarkastella järjestelmän ympäristökestävyyttä parantavia mahdollisuuksia.

Elinkaariarviointi perustui broilerin fileesuikaleiden todellisiin tuotantoprosesseihin vuosina 2003-2005, ja siihen sisällytettiin kaikki olennaiset vaiheet rehuntuotannossa tarvittavien tuotantopanosten valmistamisesta ja untuvikkojen tuotannosta aina kaupassa myytäviin valmiisiin tuotteisiin asti. Elinkaaren vaiheista selvitettiin primäärienergian käyttö, viljelyyn tarvittava peltopinta-ala, sivuvirtojen lajit, määrät ja käyttökohteet, kaatopaikkajätteen määrä sekä suorat ja välilliset päästöt ilmaan ja vesistöihin. Ympäristökuormitustiedoista laskettiin vaikutukset ilmastonmuutokseen, happamoitumiseen, vesien rehevöitymiseen ja alailmakehän otsonin muodostumiseen.

Tutkituissa ympäristövaikutusluokissa broilerien kasvatus ja rehun tuotanto muodostivat valtaosan koko toimintoverkon aiheuttamista vaikutuksista. Broilerien rehuketjun merkitys näkyi selvimmin ilmastonmuutosvaikutuksessa (36\% koko toimintoverkon ilmastonmuutosvaikutuksesta), primäärienergian kulutuksessa (25\%) ja rehevöitymisessä (66\%). Broilerien kasvattamisen merkitys oli merkittävin tuotantovaihe happamoitumisen (60\%) ja alailmakehän otsonin muodostumisen (57 \%) kannalta.

Toimintoverkon primäärienergian tarpeesta noin $90 \%$ katettiin uusiutumattomilla energianlähteillä. Rehuketjun lisäksi broilerien kasvatus, pakkausten valmistaminen ja vähittäiskauppa olivat merkittäviä energian käyttäjiä. Energiankulutuksen ja hiilidioksidipäästöjen välillä oli selvä yhteys, mutta muihin päästöihin energiankulutus ei koko toimintoverkon tasolla heijastunut. Hiilidioksidi oli eniten ilmastonmuutosta aiheuttava kasvihuonekaasu. Sen päästöt myös jakaantuivat tasaisemmin toimintoverkon eri osiin kuin muut kasvihuonekaasupäästöt, jotka olivat pääosin rehuntuotannon ja broilerinkasvatuksen metaani- ja dityppioksidipäästöjä. Torjunta-aineiden ekotoksisuusvaikutustarkastelu paljasti marinadin valmistamiseen tarvittavan rypsin viljelyn aiheuttavan noin $95 \%$ toimintoverkon kaikesta torjunta-aineiden käytöstä johtuvasta ekotoksisuusvaikutuksesta, vaikka rypsin osuus pellonkäytöstä oli vain kymmenesosa.

Yhdennetyssä ympäristövaikutusten tarkastelussa rehevöittävät päästöt muodostivat lähes puolet ja happamoittavat päästöt noin neljäsosan tuotejärjestelmän kokonaisympäristövaikutuksista. Näin ollen rehuviljan viljelyn ja broilerien kasvattamisen päästöjen vähentämisellä saavutettaisiin merkittävimmät ympäristöhyödyt.

Asiasanat: elinkaariarviointi, ympäristövaikutukset, broileri, toimintoverkko, rehun tuotanto, lanta, ammoniakki, ravinnekuormitus, maatalous. 


\section{Johdanto}

Kasvava kulutus ja kansalaisten käyttämät tuotteet ovat välittömästi tai välillisesti useimpien teollisuusmaiden ympäristöongelmien takana. Tuotelähtöinen ympäristöpolitiikka ja -hallinta perustuu elinkaariajatteluun. Sen keskeinen lähtökohta on, että kaikki tuotteen valmistamiseen, jakeluun, käyttöön ja käytöstä poistoon liittyvät toiminnot aiheuttavat ympäristöhaittoja. Riittävän tiedon hankkimiseksi tuotteen ympäristövaikutuksista on siis tarkasteltava kaikkia tuotteen suoraan ja välillisesti vaatimien toimintojen aiheuttamia ympäristövaikutuksia. Nissisen ym. (2006) kansantalouden panostuotostilastojen pohjalta tekemän arvion mukaan elintarvikkeiden osuus kulutuksen ympäristöhaitoista Suomessa on noin kolmannes.

Maa- ja elintarviketalouden tutkimuskeskuksen koordinoimassa Foodchaintutkimuskokonaisuudessa (www.mtt.fi/foodchain, 2000-) yleistavoitteena on ollut tuottaa todellisiin elintarvikkeiden tuotantoketjuihin perustuvaa elinkaaripohjaista ympäristötietoa keskeisistä suomalaisista elintarvikkeista. Ketjujen ja niiden toimijoiden parannustoimien arvioinnin ja kohdentamisen ohella näitä tietoja voidaan käyttää asiakasinformaationa ketjun toimijoiden välillä. Koko elinkaaren kattavat tuotteiden ympäristötiedot soveltuvat myös kuluttajien kulutus- ja ostovalintojen päätöksenteon tueksi.

Aiemmissa Foodchain-tutkimuksissa on selvitetty erilaisten peruna-, maito-, vilja- ja vihannestuotteiden ympäristövaikutuksia (Katajajuuri ym. 2000, Katajajuuri ym. 2003a ja 2003b, Mikkola ym. 2006, Voutilainen ym. 2003a ja 2003b). Lisäksi Suomessa on nykyaikaisten elinkaariarvioinnin periaatteiden mukaisesti selvitetty kirjolohen ja erilaisten kalatuotteiden (Grönroos ym. 2006, Silvenius \& Grönroos 2004) ja oluen ympäristövaikutuksia (Virtanen ym. 2006) sekä vertailtu tavanomaisen ja luonnonmukaisen maidon ja ruisleivän tuotannon ympäristövaikutuksia (Grönroos \& Seppälä 2000).

Broilerinlihan tuotannon koko elinkaaren kattavia ympäristökuormituksia ei ole aiemmin selvitetty Suomessa, ja vain muutama ulkomainenkin selvitys on olemassa (esim. Widheden ym. 2001). Tutkimuksen tavoitteena oli arvioida hunajamarinoitujen broilerin fileesuikaleiden todelliseen tuotantoketjuun ja -prosesseihin pohjautuvat ympäristökuormitukset ja -vaikutukset, yksilöidä niihin eniten vaikuttavat elinkaaren osat sekä niiden pohjalta etsiä ja tarkastella toimintoverkon parannusmahdollisuuksia.

\section{Aineisto ja menetelmät Elinkaariarviointi}

Tarkastellun tuotejärjestelmän ympäristönäkökohtien arviointi perustui kansainvälisesti standardoituun elinkaariarviointimenetelmään (ISO 2006a, ISO 2006b). Tarkasteltavan järjestelmän rajauksen jälkeen toteutetussa inventaarioanalyysissä kerättiin määrätiedot tuotejärjestelmän käyttämille syötteille ja tuotoksille. Kerätty aineisto toimi perustana varsinaiselle ympäristövaikutusten arvioinnille, jossa arvioitiin syötteiden ja tuotosten merkitystä ympäristöhaittojen aiheuttajana.

\section{Toiminnallinen yksikkö}

Tutkimuksen toiminnallinen yksikkö oli kulutukseen myyty hunajamarinoitu broilerin fileesuikaletonni (1000 kg), joka valmistetaan ja pakataan 300, 450 ja 650 gramman pakkauksiin HK Ruokatalon Euran tuotantolaitoksella. Kaikki tulokset laskettiin ja esitetään tätä toiminnallista yksikköä kohti.

\section{Toimintoverkon rajaukset}

Toimintoverkon rungon muodostivat nuorikkokasvatus, munitus, munien haudonta, emojen ja broilerien rehujen tuotanto, turvekuivikkeen tuotanto, broilerien kasvatus, broilerien teurastus ja jalostus hunajamarinoiduiksi fileesuikaleiksi, kuluttaja- ja kuljetuspakkauksen valmistus, rypsiöljyn tuotanto, sekä valmiin tuotteen valtakunnallinen jakelu ja säilytys kaupassa. Järjestelmän rungon lisäksi toimintoverkon rajauksiin sisällytettiin mm. kaikki kuljetukset sekä polttoaineiden ja energian tuotanto.

Tutkimuksen ulkopuolelle rajattiin järjestelmän infrastruktuuri, ihmistyö ja koneiden, laitteiden ja rakennusten valmistus. Tuotejärjestelmästä rajattiin ulkopuolelle myös joidenkin apu- ja lisäaineiden sekä torjunta-aineiden valmistus ja kuluttaja. Lisäksi broilerien isovanhempaissukupolvi ja emountuvikkojen haudonta rajattiin tutkimuksen ulkopuolelle. 


\section{Aineisto ja allokoinnit}

Tutkimuksessa sovellettu tiedonhankintastrategia tähtäsi mahdollisimman edustavan, hyvin todellisuutta kuvaavan arvion aikaansaamiseen broilerin fileesuikaleiden kokonaisympäristövaikutusten nykytilasta. Tiedot pyrittiin keräämään olennaisilta osiltaan suoraan toimintoverkon toimijoilta.

Teurastuksen ja broilerinlihatuotteiden valmistamisen tiedot ovat peräisin HK Ruokatalon Euran teurastamolta. HK Ruokatalon kasvattajien kirjanpitotietoja käytettiin hyväksi muun muassa rehunkulutus- ja tuotantomäärien arvioinnissa. Rehutehtaan tiedot ovat peräisin Suomen Rehulta. Broilerikasvattajilta, Suomen Rehun viljatutkimuksesta ja ProAgrian lohkotietokannasta saatiin tiedot rehuviljan ja rypsin viljelytoimenpiteistä ja peltojen viljavuusfosforipitoisuudesta. Rehukasvien viljelyn ja lannankäsittelyn kasvihuonekaasupäästöjen arviointiin käytettiin IPCC:n oletuspäästökertoimia ja broilerinkasvatuksen ammoniakkipäästöarvio perustui koti- ja ulkomaisiin mittaustietoihin sekä ruokinnan ravinnetaselaskelmien ja lanta-analyysitietojen kautta tehtyyn laskelmaan. Peltoviljelyn fosforipäästöt on laskettu Ekholmin ym. (2005) menetelmällä, jossa pellon helppoliukoisen fosforin pitoisuus (Pluku) on yksi tärkeimmistä lähtötiedoista. Typpihuuhtouman arviointi pohjautuu alun perin Tapio Salon (MTT) kehittämään typpitaseeseen perustuvaan laskentatapaan (Grönroos 2003). Valmiiden tuotteiden valtakunnallisen jakeluprofiilin mallintaminen tehtiin yhteistyössä HK Ruokatalon kuljetuspalvelujen toimittajien sekä Ruokakeskon ja Keslogin asiantuntijoiden kesken. Koko jakelulogistiikan polttoaineenkulutus ja päästöt laskettiin VTT:n LIISA-mallin (http://www.vtt.fi/rte/projects/lipasto/index.htm) yksikköpäästöjen avulla. Vähittäiskauppojen kautta tapahtuva tuotteiden myynti mallinnettiin Keskon vähittäistavaraliikkeiden tiedoilla. Tietolähteet ja laskentamenetelmät on esitetty yksityiskohtaisesti Katajajuuren ym. (2006) julkaisussa.

Maataloustuotannossa ja elintarvikkeiden jatkojalostuksessa syntyy monesti useita tuotteita samassa prosessissa. Käsiteltäessä tällaisia järjestelmiä tarvitaan allokointimenettelyjä, joissa materiaalija energiavirrat samoin kuin niihin liittyvät päästöt ja muut kuormitukset allokoidaan eli jyvitetään eri tuotteille selvästi määriteltyjen menettelytapojen mukaan. Tutkimuksessa allokointeja tehtiin muun muassa kohdennettaessa rypsipuristamon syötteet ja tuotokset rypsiöljylle ja -rouheelle ja jaettaessa teurastuksen ja lihatuotteiden valmistamisen syötteet ja tuotokset eri lihatuotteille. Asiaa käsitellään tarkemmin Katajajuuren ym. (2006) julkaisussa.

\section{Ympäristövaikutusten arviointi}

Vaikutusarviointimallilla muutettiin inventaarioanalyysissä kerättyjen kuormitustekijöiden haittavaikutukset vaikutuskokonaisuuksiksi, nk. vaikutusluokkaindikaattoriarvoiksi, joiden laskemisessa käytettiin elinkaariarvioinneissa yleisesti käytettyjä ja kansainvälisen vaikutusarviointimetodologian mukaisia yhtälöitä. Vaikutusluokkaindikaattoriarvon laskemisessa kyse on erityyppisten päästömuuttujien yhteismitallistamisesta ja summaamisesta. Esimerkiksi ilmastonmuutoksessa kolmen eri kasvihuonekaasun päästömäärät voidaan laskea yhteen ns. GWP-kertoimilla, joista käytetään myös nimitystä karakterisointikertoimet. Eri ympäristövaikutusluokissa käytetyt karakterisointikertoimet on esitetty julkaisussa Katajajuuri ym. (2006). Vaikutusluokkaindikaattorien normalisointi ja painotus (ks. ISO 2006b) mahdollistavat eri vaikutusluokkaindikaattoriarvojen laskemisen yhteen, jolloin saadaan kokonaishaitallisuutta kuvaava ympäristövaikutusindeksi ja nähdään, mistä kokonaisympäristövaikutus muodostuu. Painotukseen liittyvän subjektiivisuuden takia painotettuja tuloksia ei tule esittää erillään vaikutusluokkakohtaisista tuloksista.

\section{Tulokset ja tulosten tarkastelu}

Viljelypinta-alaa tarvittiin toiminallista yksikköä kohden kokonaisuudessaan 0,76 hehtaaria sisältäen myös kotimaisen viljelyn kesannoinnin ja kylvösiementen tuotantoalat. Broilerirehujen osuus kokonaispinta-alasta oli $83 \%$ lopun alan muodostuessa marinadissa tarvittavan rypsin tuotantoalasta ja nuorikkojen ja emojen rehun viljelyalasta.

Hunajamarinoitua broilerin fileesuikaletonnia kohti toimintoverkon kaikissa vaiheissa kului primäärienergiaa yhteensä noin 42,3 GJ, josta rehuntuotantoketju muodosti neljänneksen (kuva 1). Myös kaupan osuus oli merkittävä viidesosan osuudellaan, samoin kuin broilerien kasvatuksen ja pakkausten valmistamisen osuus, joiden kummankin osuus kokonaisenergiankulutuksesta oli noin $15 \%$.

Toimintoverkon ilmastonmuutosvaikutuksesta ylivoimaisesti suurin osa $(65 \%)$ aiheutui broilerien kasvatuksesta ja rehuketjusta (kuva 2). Toimintoverkon ilmastonmuutosvaikutuksesta lähes $60 \%$ aiheutui hiilidioksidipäästöistä. Energiaperäisten päästöjen ohella ilmastonmuutoksen voimistumiseen 
vaikuttavat mm. kalkituksessa vapautuva hiilidioksidi, lannoitteiden käytössä ja tuotannossa vapautuva dityppioksidi sekä broilerien lannan käsittelystä syntyvät metaani- ja dityppioksidipäästöt.

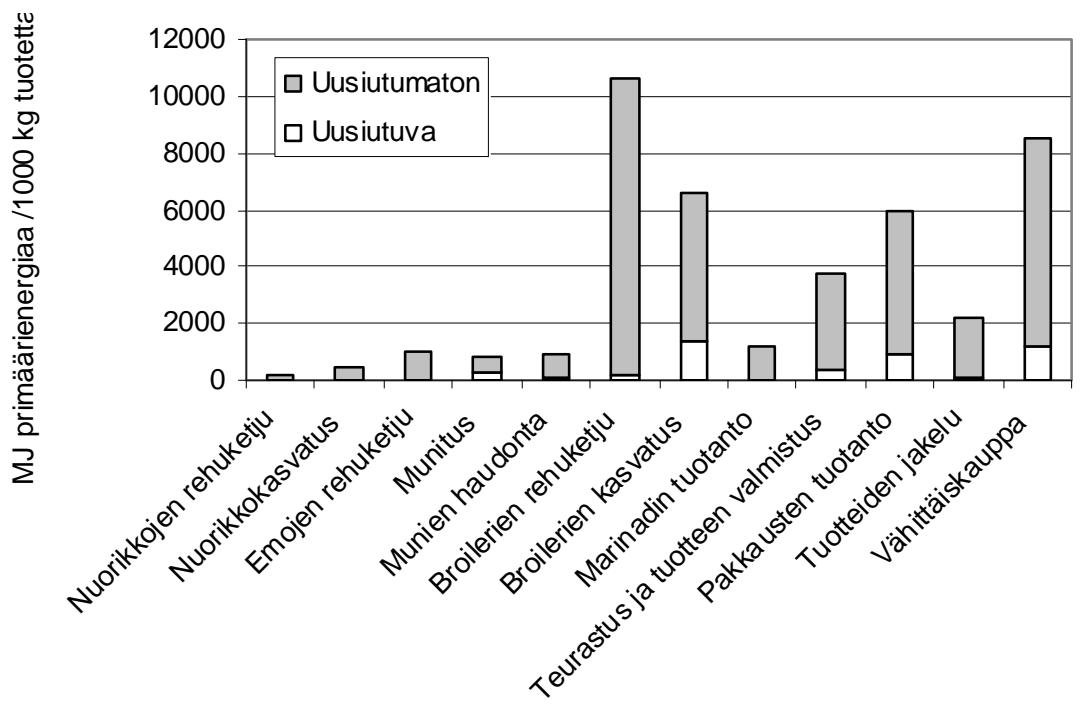

Kuva 1. Hunajamarinoitujen broilerin fileesuikaleiden primäärienergiankulutus toimintoverkon eri vaiheissa 1000 tuotekiloa kohden jaettuna uusiutuviin ja uusiutumattomiin energianlähteisiin.

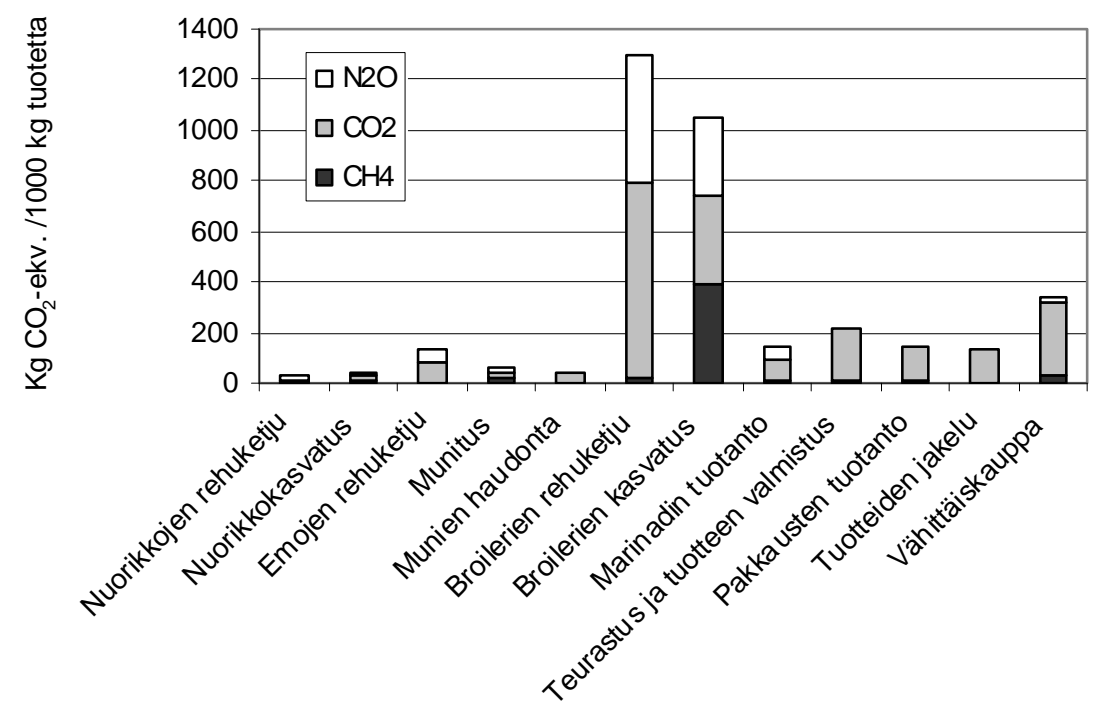

Kuva 2. Hunajamarinoitujen broilerin fileesuikaleiden tuotannon ilmastonmuutosvaikutuksen muodostuminen tuotantovaiheittain ja kuormitustekijöittäin 1000 tuotekiloa kohden.

Ylivoimaisesti suurin merkitys happamoitumiseen oli broilerien kasvatuksesta aiheutuvilla ammoniakkipäästöillä (kuva 3). Muita broilerin tuotannon happamoitumista aiheuttavia tekijöitä olivat lähinnä rehuketjujen työkoneiden ja kuljetusten $\mathrm{NO}_{\mathrm{x}} \mathrm{ja} \mathrm{SO}_{2}$ päästöt sekä väkilannoitteiden käytössä haihtuva ammoniakki.

Toimintoverkon rehevöittävistä vaikutuksista lähes 70 prosenttia aiheutui rehuntuotannosta rehuviljan viljelyn ravinnepäästöjen vuoksi. Toiseksi suurimman vaikutuksen aiheutti ammoniakkipäästöjen takia broilerien kasvatus noin kuudesosan osuudellaan (kuva 4). Teurastuksen ja tuotteen valmistuksen osuus vesien rehevöitymiseen on hyvin pieni, vain noin yksi prosentti koko toimintoverkon rehevöittävästä vaikutuksesta.

Alailmakehän otsonin muodostumiseen vaikuttavia päästöjä aiheutui eniten broilerien kasvatuksesta (lähes $60 \%$, kuva 5). Merkittävin otsonin muodostumiseen vaikuttava kuormitustekijä oli broilerin lannasta vapautuva metaani. Toiseksi suurin merkitys oli broilerirehun tuotannolla, jonka osuus oli noin kuudennes. 


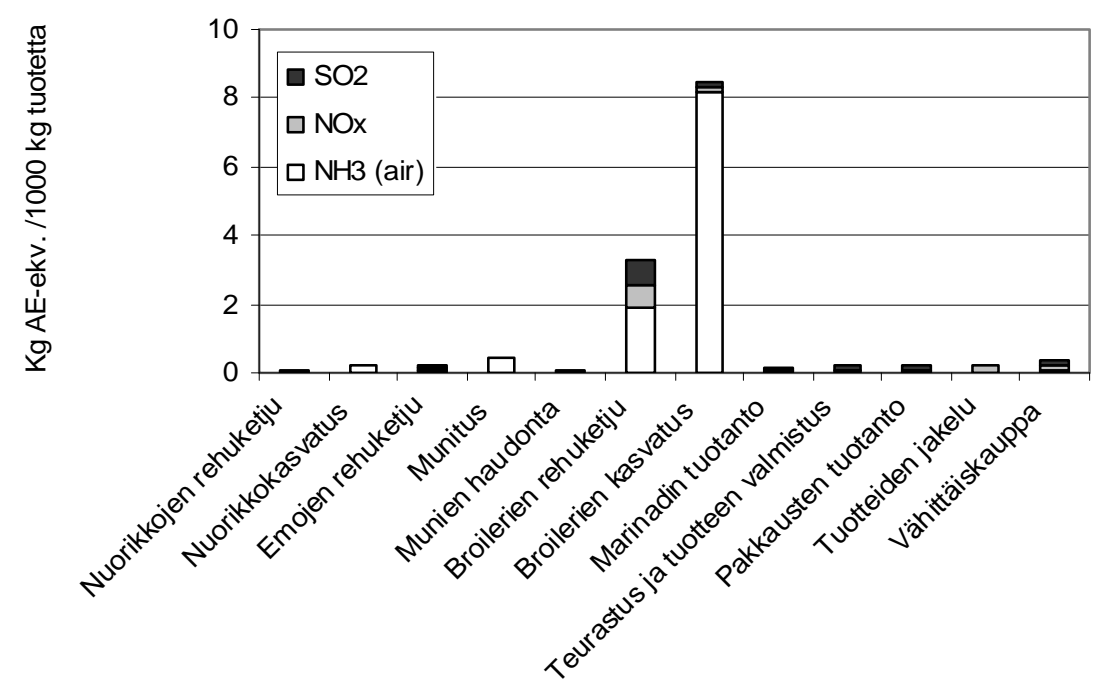

Kuva 3. Hunajamarinoitujen broilerin fileesuikaleiden toimintoverkon happamoitumispotentiaalin muodostuminen tuotantovaiheittain ja kuormitustekijöittäin 1000 tuotekiloa kohden.

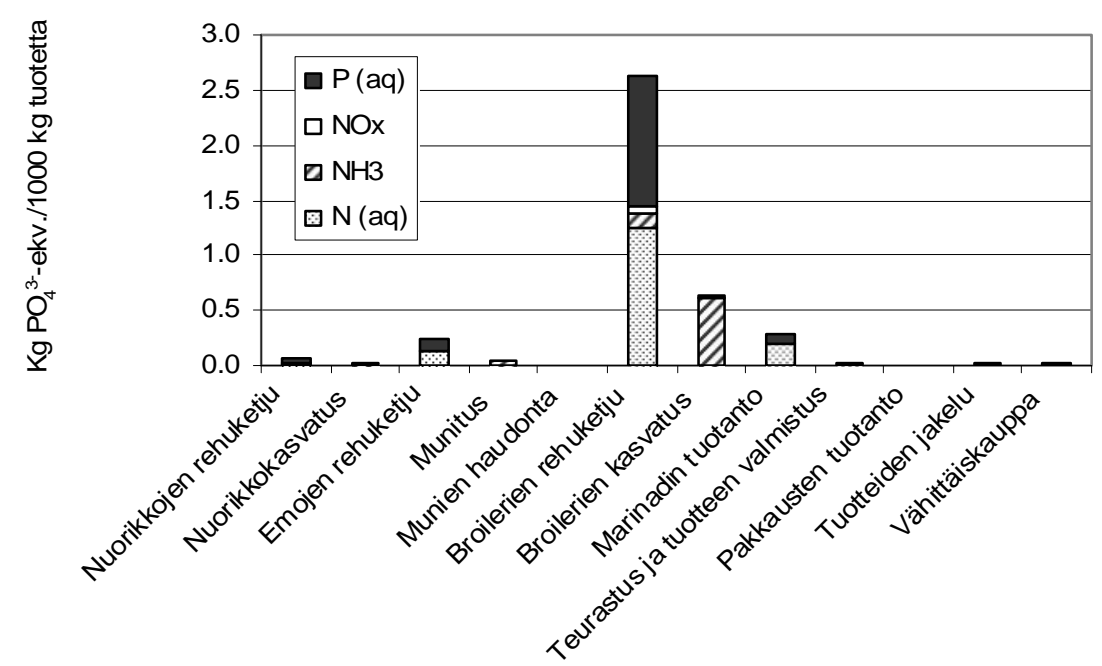

Kuva 4. Hunajamarinoitujen broilerin fileesuikaleiden toimintoverkon rehevöitymisvaikutuksen muodostuminen tuotantovaiheittain ja kuormitustekijöittäin 1000 tuotekiloa kohden.

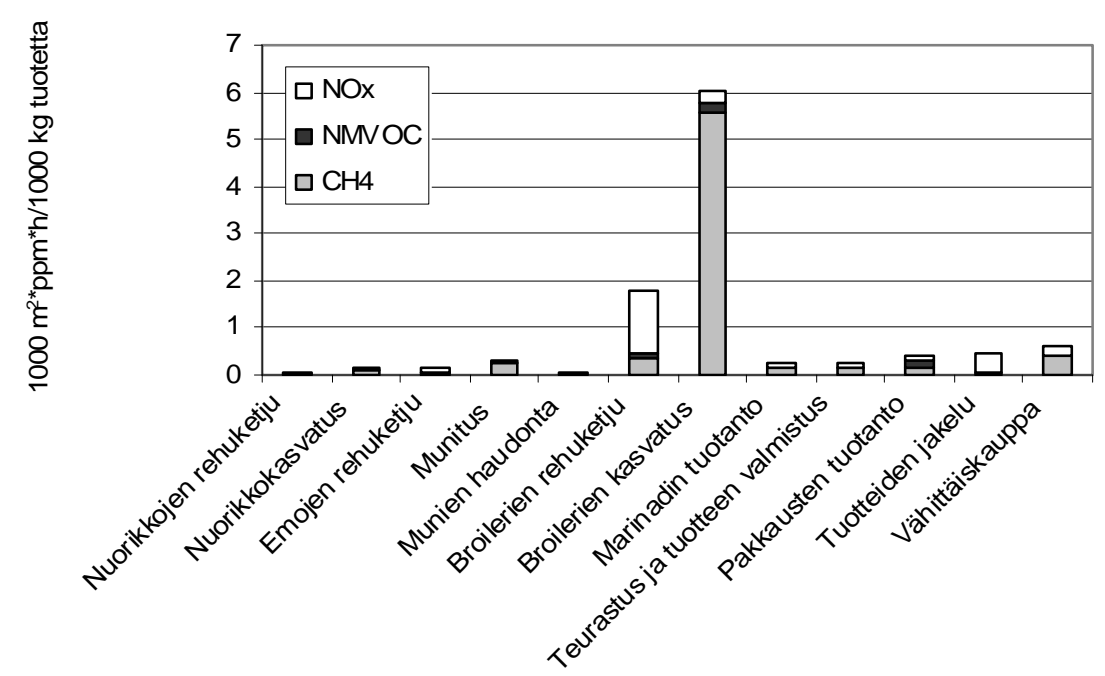

Kuva 5. Alailmakehän otsonin muodostuminen hunajamarinoitujen broilerin fileesuikaleiden tuotannossa tuotantovaiheittain ja kuormitustekijöittäin 1000 tuotekiloa kohden. 
Ympäristövaikutusten yhdennetty tarkastelu osoitti, että rehevöittävät päästöt muodostavat lähes puolet ja happamoittavat päästöt noin neljäsosan tuotejärjestelmän kokonaisympäristövaikutuksista. Näin ollen merkittävimmät parannuspotentiaalit löytyvät rehuviljan viljelystä ja varsinaisesta broilerien kasvattamisesta (ks. tarkemmin Katajajuuri ym. 2006).

Ympäristövaikutustarkastelun yhteydessä arvioitiin toimintoverkossa käytettyjen torjuntaaineiden ekotoksisuutta vesieliöille. Sitä ei voitu yhdistää ympäristövaikutusten yhdennettyyn tarkasteluun, mutta se paljasti, että rypsin tuotannossa käytetyt torjunta-aineet vastasivat noin $95 \%$ toimintoverkon kaikesta torjunta-aineiden aiheuttamasta ekotoksisuusvaikutuksesta, vaikka rypsin osuus peltoalantarpeesta oli vain $10 \%$. Tulos johtuu ennen kaikkea rapsikuoriaisen ja kirppojen torjunnassa käytettyjen insektisidien suuresta ekotoksisuuspotentiaalista vesieliöille muihin torjunta-aineisiin verrattuna.

\section{Tulosten tarkastelu}

Vaikutusarvioinnin tulosten mukaan merkittävimmät päästöt syntyvät peltoviljelyssä ja broilerien hallikasvatuksessa. Näissä tuotantovaiheissa syntyvien päästöjen suuruuden arviointiin sisältyy myös merkittäviä epävarmuuksia. Peltoviljelyn ravinnepäästöt ja hallikasvatuksen ammoniakkipäästöt vaihtelevat tapauskohtaisesti, ja varsinkin ensin mainittuihin liittyy merkittäviä säätekijöistä johtuvia vaihteluita. Kyseisiin päästöihin liittyvät epävarmuudet eivät kuitenkaan vaikuta lopullisiin johtopäätöksiin rehuntuotannon ja kasvatusvaiheen tärkeydestä ympäristövaikutusten muodostajina.

Tutkimuksessa ei kyetty käsittelemään kaikkia maataloustuotteiden tuotantoon liittyviä ympäristövaikutuksia, kuten vaikutuksia luonnon monimuotoisuuteen tai maan viljavuuteen. Myös näiden nyt vähemmälle huomiolle jääneiden vaikutusten huomioiminen johtaisi maatilavaiheen merkityksen kasvamiseen. Tuotannosta aiheutuvia ekotoksisia vaikutuksia tarkasteltiin vertailemalla erilaisten torjunta-aineiden haitallisuutta ja kulkeutumista ympäristöön, mutta käytetty menetelmä ei mahdollistanut ekotoksisten vaikutusten rinnakkaista tarkastelua muiden vaikutusluokkien kanssa. Menetelmä kuitenkin mahdollisti eri torjunta-aineiden keskinäisen haitallisuuden vertailun, mikä jo sinänsä on mielenkiintoista ja auttaa hahmottamaan merkittävimmät tuotantovaiheet ekotoksisuuden kannalta.

\section{Johtopäätökset}

Prosessin ja päästöjen hallintaan on maataloudessa huonommat lähtökohdat kuin teollisuudessa yhtäl̈ltä maatalouden päästöjen hajakuormitusluonteen takia ja toisaalta, koska maataloudessa toimitaan luonnonolojen ehdoilla. Lisäksi maatalouden suuri osuus vesien ravinnekuormituksesta Suomessa ja rehevöitymisen vähentämisen suuri tärkeys suhteessa muihin ympäristöongelmiin aiheuttavat sen, että ravinnekuormituksen rooli ympäristövaikutusten aiheuttajana korostuu, ja se myös on pääselitys sille, miksi rehujen tuotanto nousee tärkeimmäksi tuotantovaiheeksi ympäristövaikutusten muodostajana.

Peltoviljelyn päästöjen vähentämiseen on olemassa keinoja, kuten typpilannoituksen tarkentaminen, fosforilannoituksen vähentäminen ja maan helppoliukoisen fosforin pitoisuuden alentaminen, peltomaan hyvän vesitalouden ja rakenteen ylläpitäminen, paremmin ravinteita hyödyntävien viljelykasvien kehittäminen, eroosion vähentäminen muokkausta muuttamalla, valumavesiä puhdistavien kosteikkojen perustaminen, viljelyn vähentäminen huonotuottoisimmilla lohkoilla ja vesien kuormittumisen kannalta epäedullisimpien lohkojen muuttaminen suojavyöhykkeiksi. Tehokas kuormituksen vähentäminen edellyttää keinojen laajaa yhtäaikaista käyttöä.

Broilerin lannan aiempaa tehokkaammalla hyödyntämisellä varsinkin fosforiköyhimpien peltojen lannoitteena on suorien huuhtoumavaikutusten lisäksi vaikutusta myös väkilannoitteiden käyttöön ja sitä kautta lannoitteiden valmistuksen energiankulutukseen. Broileritiloilla lannanlevitykseen sopivaa peltoa ei yleensä ole riittävästi, minkä takia lähiseudun kasvinviljelytilat olisi saatava kiinnostumaan lannasta väkilannoitteiden korvaajana.

Broilerien kasvatuksessa päähuomio kiinnittyy ammoniakkipäästöihin ja energiankulutukseen. Parhaimmassa tapauksessa ammoniakkipäästöjä voidaan vähentää vaikuttamalla jo niiden syntymekanismeihin. Tässä kuivikepatjan ominaisuuksilla on suuri merkitys. Se vaikuttaa myös lintujen hyvinvointiin, koska korkeat ammoniakkipitoisuudet aiheuttavat linnuille iho- ja hengitystievaurioita. Kuivikemateriaalin merkitys päästöihin ja eläinten hyvinvointiin havaittiinkin tärkeäksi uudeksi tutkimusaiheeksi. Ammoniakkipäästöjen vähentäminen on perusteltua myös hajuhaittojen vähentämiseksi. Jos ammoniakin haihtumista lannasta voidaan vähentää, se parantaa myös lannan lannoitusvaikutusta. Toinen tapa vähentää ammoniakkipäästöjä on sen poistaminen kasvattamon poistoilmasta. 
Kasvattamojen energiankulutusta voidaan alentaa lämmön talteenottolaitteistoilla. Melko vaatimattomallakin hyötysuhteella toimivalla lämmönsiirtimellä voidaan energiankulutusta pienentää kolmanneksella. Taloudellisesti järkevän ratkaisun kehittämiseksi rakennuksen ilmanvaihtoa, lämmitystä ja tuotanto-olosuhteita on tarkasteltava kokonaisuutena. Ammoniakin erottaminen poistoilmasta vähentää suoraan broilerien kasvatusvaiheen ympäristövaikutuksia. Koska samalla myös poistoilman pölypitoisuus pienenee, paranevat lämmönsiirtimien toimintaedellytykset. Tämä puolestaan mahdollistaa kasvattamon ilmanvaihdon tehostamisen, jolloin kuivikepohja pysyy kuivempana ja ammoniakkia haihtuu vähemmän millä on positiivinen vaikutus lintujen terveyteen.

Elinkaaritarkastelut antavat aiempaa paremmat mahdollisuudet toimintoverkon toimijoille tarkastella toimintaansa ja sen vaikutuksia ympäristöön. Tarkastelujen kautta myös kuluttajilla on entistä paremmat mahdollisuudet perehtyä tuotteiden tuotantoon koko elinkaaren osalta. Maataloustuotanto aiheuttaa merkittävän osan koko ketjun päästöistä. Ketjun loppupäällä on kuitenkin viime kädessä suuri vastuu siinä, minkälainen markkinoille tarjottu tuote ympäristövaikutuksiltaan on. Sillä on myös mahdollisuuksia vaikuttaa ketjun aiempien vaiheiden toimintatapoihin, mitä sen pitäisikin jatkossa enemmän hyödyntää.

\section{Kirjallisuus}

Grönroos, J. \& Seppälä, J. (toim.) 2000. Maatalouden tuotantotavat ja ympäristö. Helsinki, Suomen ympäristökeskus, Suomen ympäristö 431. 243 s.

Grönroos, J. (toim.) 2003. Erilaisten maatalouskäytäntöjen ravinnehuuhtoumien arviointi. Suomen ympäristökeskus. Helsinki 22.9.2003. Tutkimushankkeen loppuraportti maa- ja metsätalousministeriölle. $33 \mathrm{~s}$.

Grönroos, J., Seppälä, J., Silvenius, F. \& Mäkinen, T. 2006. Life cycle assessment of cultivated rainbow trout. Boreal Environment Research 11: 401-414.

ISO (International Organization for Standadization) 2006a. Environmental management. Life cycle assessment. Principles and framework. ISO 14040.

ISO (International Organization for Standadization) 2006b. Environmental management. Life cycle assessment. Requirements and guidelines. ISO 14044.

Katajajuuri, J.-M., Grönroos, J., Usva, K., Virtanen, Y., Sipilä, I., Venäläinen, E., Kurppa, S., Tanskanen, R., Mattila, T. \& Virtanen, H. 2006. Broilerin fileesuikaleiden tuotannon ympäristövaikutukset ja kehittämismahdollisuudet. Maa- ja elintarviketalous 90.118 s. http://www.mtt.fi/met/pdf/met90.pdf

Katajajuuri, J.-M., Loikkanen, T. Pahkala, K., Uusi-Kämppä, J., Voutilainen, P., Kurppa, S., Laitinen, P., Mikkola, H., Kivinen, T. \& Salo, S. 2000. Ympäristöhallintaa tukevan tietopohjan kehittäminen osana maatilojen laatujärjestelmää. Case: Rehuohran elinkaariarviointi. VTT Kemiantekniikka, Espoo. 134 s. VTT Tiedotteita 2034. http://virtual.vtt.fi/inf/pdf/tiedotteet/2000/T2034.pdf

Katajajuuri, J.-M., Virtanen, Y., Voutilainen, P., Tuhkanen, H.-R. \& Kurppa, S. 2003a. Elintarvikkeiden ympäristövaikutukset FOODCHAIN. MMM:n julkaisuja 6/2003. Maa- ja metsätalousministeriö. 63 s. http://www.mmm.fi/julkaisut/julkaisusarja/MMMjulkaisu2003_6.pdf

Katajajuuri, J.-M., Voutilainen, P., Tuhkanen, H.-R. \& Honkasalo, N. 2003b. Elovena-kaurahiutaleiden ympäristövaikutukset. Maa- ja elintarviketalous 33, 47 s. http://www.mtt.fi/met/pdf/met33.pdf

Mikkola, A., Katajajuuri, J.-M., Grönroos, J., Voutilainen, P., Näkkilä, J. \& Hovi-Pekkanen, T. 2007. Kasvihuonekurkun tuotantoketjun ympäristövaikutukset ja niiden vähentämismahdollisuudet. Maa- ja elintarviketalous. Käsikirjoitus.

Nissinen, A., Grönroos, J., Heiskanen, E., Honkanen, A., Katajajuuri, J.-M., Kurppa, S., Mäkinen, T., Mäenpää, I., Seppälä, J., Timonen, P., Usva, K., Virtanen, Y. \& Voutilainen, P. 2007. Developing benchmarks for consumer-oriented LCA-based environmental information on products, services and consumption patterns. Journal of Cleaner Production 15, 6/2007: p. 538-549.

Silvenius, F. \& Grönroos, J. 2004. Suomen kalatuotteiden elinkaariarviointi. Suomen ympäristö 629. Suomen ympäristökeskus. Helsinki. $101 \mathrm{~s}$.

Virtanen, Y., Usva, K. \& Katajajuuri, J.-M. 2006. Mallasohra -toimintoverkon kestävyyden parantamisen työkalut (MOKE) - Suomalaisen keskioluen ympäristövaikutusten elinkaariarviointi ja analyysi kokonaisympäristövaikutuksista. Luottamuksellinen. Julkaistaan vuonna 2007.

Voutilainen, P., Tuhkanen, H.-R., Katajajuuri, J.-M., Nousiainen, J. \& Honkasalo, N. 2003a. Kesäpöytä Juustokermaperunoiden ja Pirkka perunajauhon ympäristövaikutukset. Maa- ja elintarviketalous 2003: 34. http://www.mtt.fi/met/pdf/ met34.pdf

Voutilainen, P., Tuhkanen, H.-R., Katajajuuri, J.-M., Nousiainen, J. \& Honkasalo, N. 2003b. Emmental Sinileima -juuston tuotantoketjun ympäristövaikutukset ja parannusmahdollisuudet. Maa- ja elintarviketalous (2003):35, 91 s. http://www.mtt.fi/met/pdf/met35.pdf

Widheden, A., Strömberg, K., Andersson, K. \& Ahlmén, K. 2001. LCA kyckling. CIT Ekologik Ab \& Miljöledarna Ciconia Ab. 87 s. 